\title{
Pengembangan Sentra Kuliner Di Desa Candinegoro Kecamatan Wonoayu, Kabupaten Sidoarjo
}

\author{
Laily Endah Fatmawati ${ }^{*}$, Gede Sarya ${ }^{2}$, Dery Dwi Fitriansyah ${ }^{3}$ \\ 1,2,3 Universitas 17 Agustus 1945 Surabaya \\ e-mail: lailyendah@untag-sby.ac.id ${ }^{1}$, gedesarya@untag-sby.ac.id ${ }^{2}{ }_{2}$ deryyansyah@gmail.com $^{3}$, \\ *Penulis Korespondensi: E-mail: lailyendah@untag-sby.ac.id
}

\begin{abstract}
Candinegoro village located in Wonoayu District, Sidoarjo Regency, East Java. The village has a Hindu-style temple site, namely Candi Dermo which is a relic of the Majapahit Kingdom, Wangsa Hayam Wuruk which was founded in 1953. Related to the efforts of the Sidoarjo Regency Government in developing Candinegoro Village to become a Tourism Village, several village development plans are needed, one of which is development in the culinary center aspect. Candi Dermo is currently quite attractive for visitors where the average visitors reaches 90-125 people every month. The number of visitors is quite small than visitors from other temples in Indonesia. Candinegoro already has culinary area located on the river bank to the north of kemasan road, candinegoro village along $200 \mathrm{~m}$. However, the location of this culinary tour is not well organized, so that it does not attract visitors for culinary tours in that place. The lack of complete facilities and infrastructure at the culinary center causes residents to be less interested in traveling in this area. To overcome this problem, a culinary center design is carried out which is equipped with the supporting facilities and infrastructure needed in the realization of culinary center development.
\end{abstract}

Keywords: Dermo Temple, Tourist Village, Culinary center

\begin{abstract}
Abstrak
Desa Candinegoro terletak di Kecamatan Wonoayu, Kabupaten Sidoarjo, Jawa Timur. Desa tersebut memiliki situs candi bercorak Hindu yakni Candi Dermo yang merupakan peninggalan pada Masa Kerajaan Majapahit, Wangsa Hayam Wuruk yang berdiri pada tahun 1953. Terkait dengan usaha Pemerintah Kabupaten Sidoarjo dalam mengembangkan Desa Candinegoro menjadi Desa Wisata, diperlukan beberapa perencanaan pengembangan desa, salah satunya pengembangan dalam aspek sentra kuliner. Candi Dermo saat ini cukup menarik minat pengunjung dimana rata-rata pengunjung mencapai 90-125 orang tiap bulannya. Jumlah pengunjung ini cukup kecil dibandingkan dengan pengunjung dari Candi lainnya di Indonesia. Candinegoro sudah memiliki area kuliner yang berada di tepi sungai sebelah utara Jalan Kemasan, Desa Candinegoro sepanjang $200 \mathrm{~m}$. Namun lokasi wisata kuliner ini kurang tertata dengan baik sehingga kurang menarik pengunjung dalam berwisata kuliner di tempat tersebut. Kurang lengkapnya sarana dan prasarana yang ada pada pusat kuliner tersebut menyebabkan warga kurang tertarik untuk berwisata di area tersebut. Untuk mengatasi permasalahan tersebut, maka dilakukan perancangan desain sentra kuliner yang dilengkapi dengan sarana dan prasarana penunjang yang diperlukan dalam realisasi pengembangan sentra kuliner.
\end{abstract}

Kata Kunci : Candi Dermo, Desa Wisata, Sentra Kuliner

\section{PENDAHULUAN}

Desa Candineogoro merupakan desa yang memiliki potensi wisata yakni Candi Dermo. Candi Dermo merupakan Candi yang dibuat pada Masa Kerajaan Majapahit, Wangsa Hayam Wuruk di tahun 1953. Candi Dermo merupakan salah satu wisata yang menjadi salah satu objek wisata tujuan warga Desa Candinegoro dan masyarakat sekitar untuk berwisata. Diketahui desa wisata merupakan harapan pemerintah unruk mencanakan Program Nasional Pemberdayaan Masyarakat (PNPM) mandiri masyarakat dalam mensinergikan pasar wisata desa untuk meningkatkan kesejahteraan masyarakat 
pedalaman. Pemerintah menggapai industri pariwisata desa sangat ramah dalam penyerapan sumber daya lokal yang bersifat Padat Karya.

Terkait dengan usaha Pemerintah Kabupaten Sidoarjo dalam mengembangkan Desa Candinegoro menjadi Desa Wisata, maka diperlukan adanya perencanaan pengembangan desa yang didukung dengan potensi desa untuk dapat menunjang aktivitas pariwisata di desa tersebut. Bila suatu Desa sudah memiliki potensi, namun tidak memiliki daya tarik tersendiri, maka hal tersebut dapat berpengaruh pada banyaknya pengunjung di Desa Wisata.

Desa Candinegoro memiliki potensi penunjang untuk Wisata Candi Dermo, yakni Sentra Kuliner / Pusat Kuliner. Letak sentra kuliner tersebut berada di tepi sungai sebelah utara jalan kemasan desa candinegoro sepanjang $200 \mathrm{~m}$. Adanya sentra kuliner ini diharapkan dapat menarik minat pengunjung desa khususnya ke Candi Dermo karena letaknya yang cukup dekat dengan lokasi Candi. Namun kenyataannya sentra kuliner ini bukan salah satu tujuan yang dituju oleh masyarakat yang berwisata ke Candi Dermo.

Sarana dan prasarana pariwisata merupakan salah satu indikator perkembangan pariwisata dimana objek pariwisata memiliki standar kelayakan menjadi daerah tujuan wisata, yakni kelayakan objek, akses, akomodasi, fasilitas, transportasi, pembelanjaan, dan sebagainya (Agusbushro, 2014). Berdasarkan latar belakang di atas, maka dilakukan perancangan desain sentra kuliner yang dilengkapi dengan sarana dan prasarana penunjang yang diperlukan dalam realisasi pengembangan sentra kuliner untuk mewujudkan salah satu kelayakan pemenuhan Desa Wisata di Desa Candinegoro, Kabupaten Sidoarjo.

\section{METODE PELAKSANAAN}

Pelaksanaan diawali dengan identifikasi permasalahan mitra, yakni dengan mengumpulkan bukti hasil survei pendahuluan dan wawancara sehingga diketahui bahwa masyarakat desa kurang mengetahui cara desain fasilitas bangunan dan kurangnya tempat yang layak dalam pengembangan usaha di bidang kuliner. Setelah mengetahui permasalahan yang dihadapi oleh warga desa Candinegoro, maka dilakukan desain sentra kuliner sebagai acuan dalam pembangunan untuk menunjang Desa Candinegoro sebagai Desa Wisata.

\section{HASIL dan PEMBAHASAN}

Kondisi eksisting lokasi pedestrian untuk rencana sentra kuliner di Desa Candineagoro Kabupaten Sidoarjo.

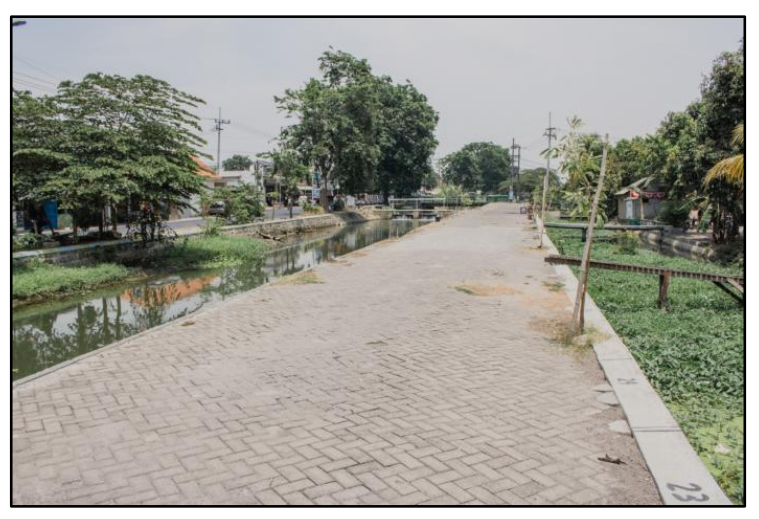

Gambar 1. Foto Lokasi Studi

(Sumber : Dokumentasi, 2020) 
Rencana pembuatan sentra kuliner didasarkan pada perencanaan Pedestrian Ways dalam Perancangan Kota (2009) dimana sentra kuliner dibuat diatas pedestrian yang direncanakan memiliki elemen-elemen sesuai buku tersebut. Dari kajian yang telah dilakukan didapatkan hasil rencana layout sentra kuliner sebagai berikut:

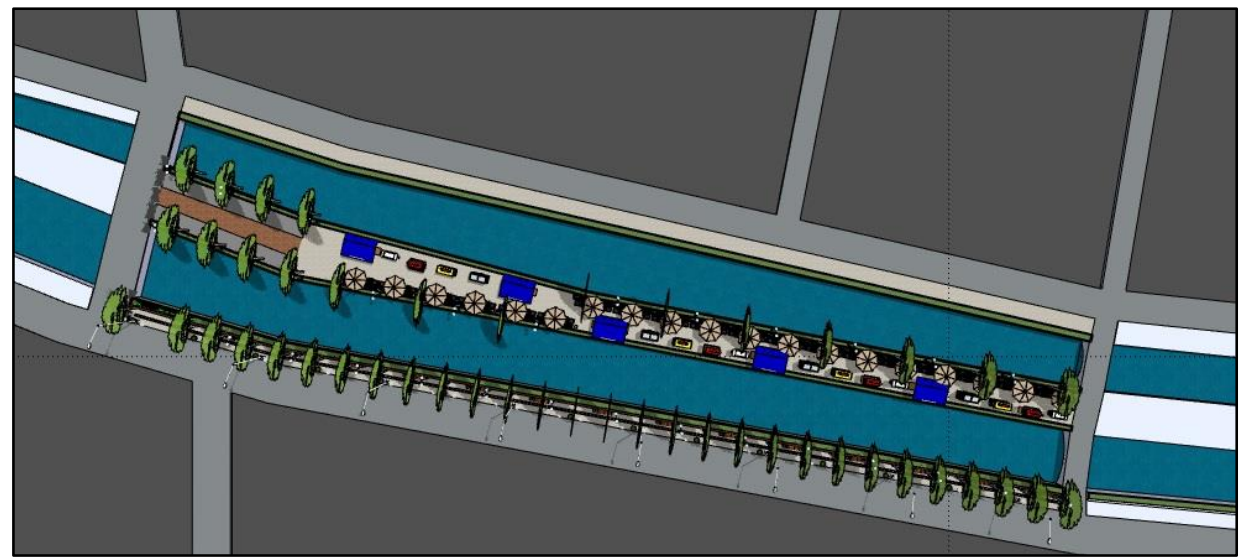

Gambar 2. Layout sentra kuliner rencana

(Sumber : Rencana Desain, 2020)

Penempatan lampu penerangan jalan diletakkan setiap 12 meter, sedangkan untuk lampu [ejalan kaki diletakkan tiap 8 meter dengan ketinggian lampu 4 meter. Dilakukan juga penanaman vegetasi tambahan untuk mengurangi dampak polusi dan menciptakan lingkungan yang asri, serta memiliki fungsi agar lebih sejuk.

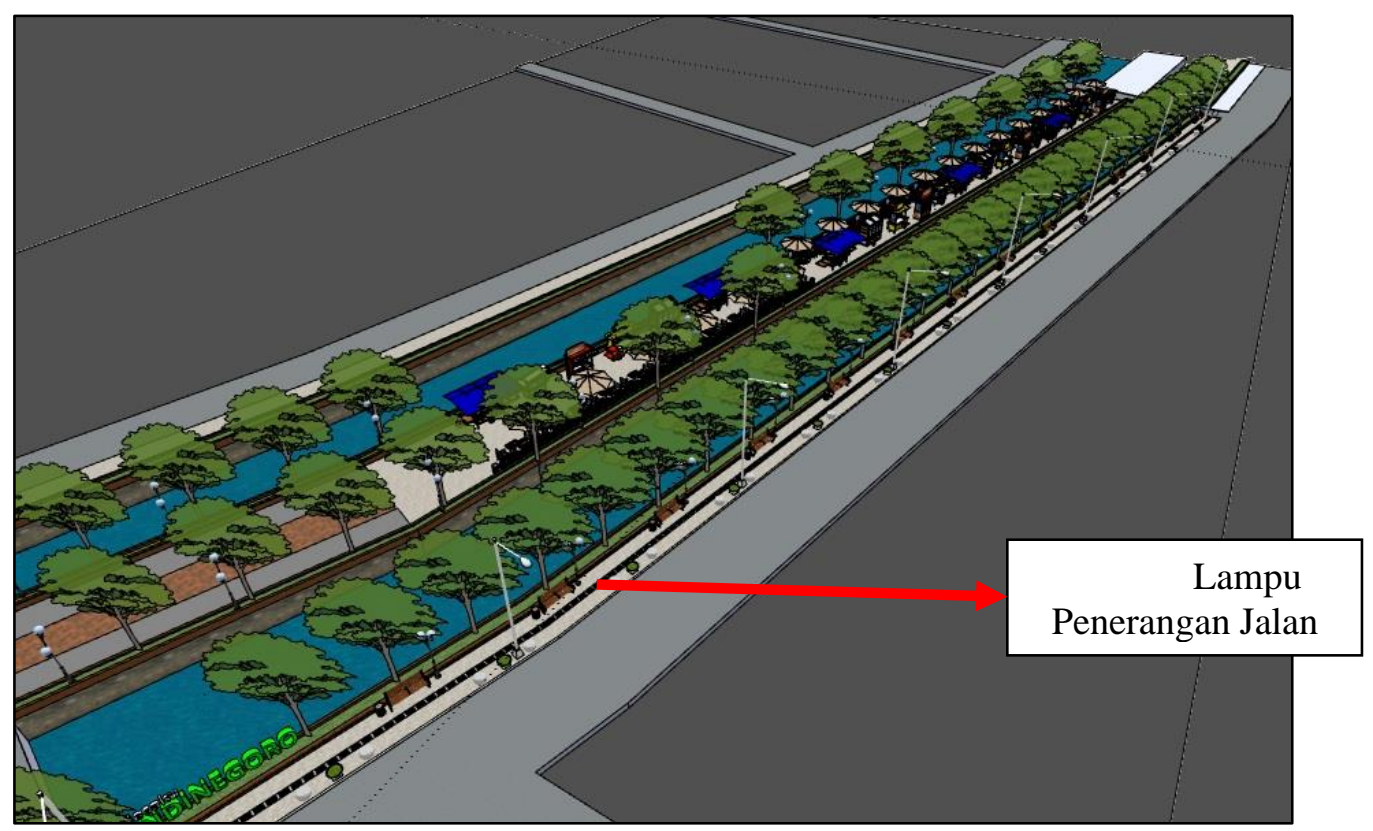

Gambar 3. Perspektif Sentra Kuliner Rencana

(Sumber : Rencana Desain, 2020)

Papan petunjuk arah sangat dibutuhkan dalam merencanakan suatu jalan akses menuju tempat wisata. Jalur penanda bagi kauf difabel cukup patut dipertimbangkan 
mengingat kita hidup di lingkup masyarakat luas dan hidup dalam bertoleransi, sehingga adanya difable track dirasa cukup penting disediakan.

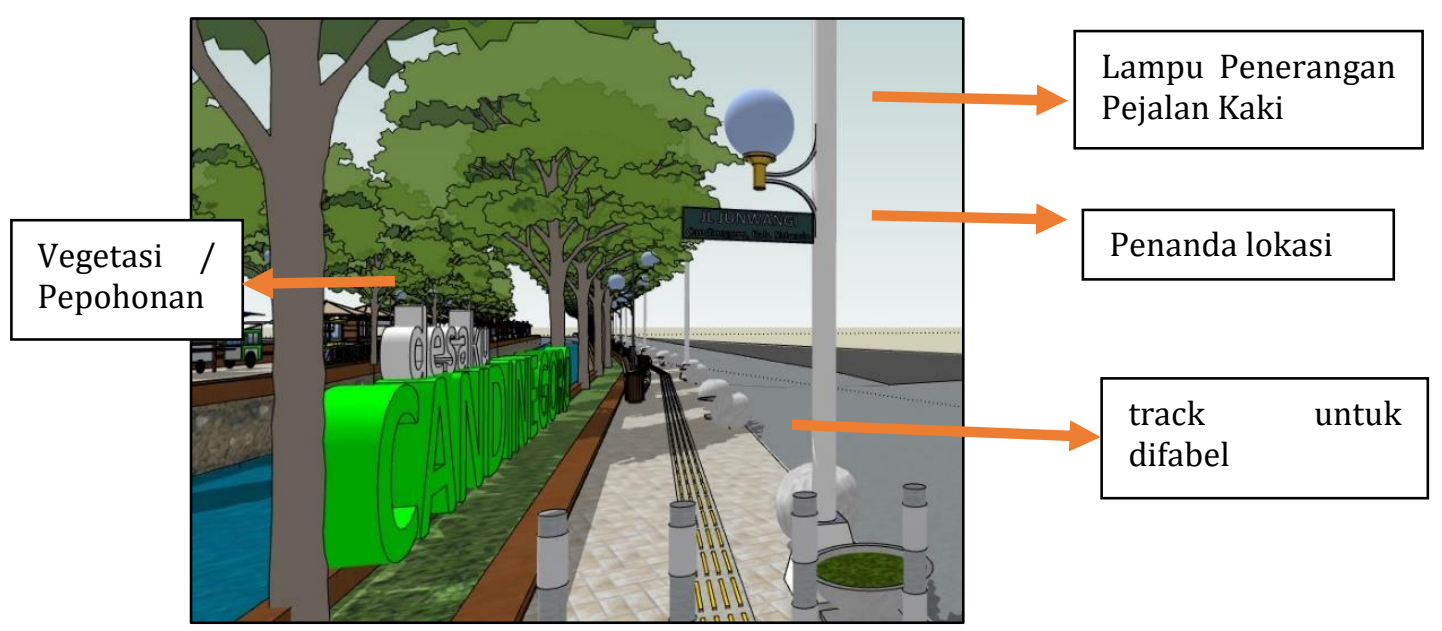

Gambar 4. Gambar Tampak Desain Pedestrian

(Sumber : Rencana Desain, 2020)

Didalam prasarana pendukung lain yang penting adalah tempat duduk untuk beristirahat dan tempat sampah. Kebutuhan tempat duduk selain untuk bersantai adalah untuk melepas lelah mengingat kapasitas kemampuan seseorang untuk berjalan kaki, sangat terbatas. Sehingga dibutuhkan tempat duduk untuk beristirahat sementara. Selanjutnya adalah tempat sampah yang sangat penting untuk memegang peranan penting dalam terjaganya kebersihan lokasi.

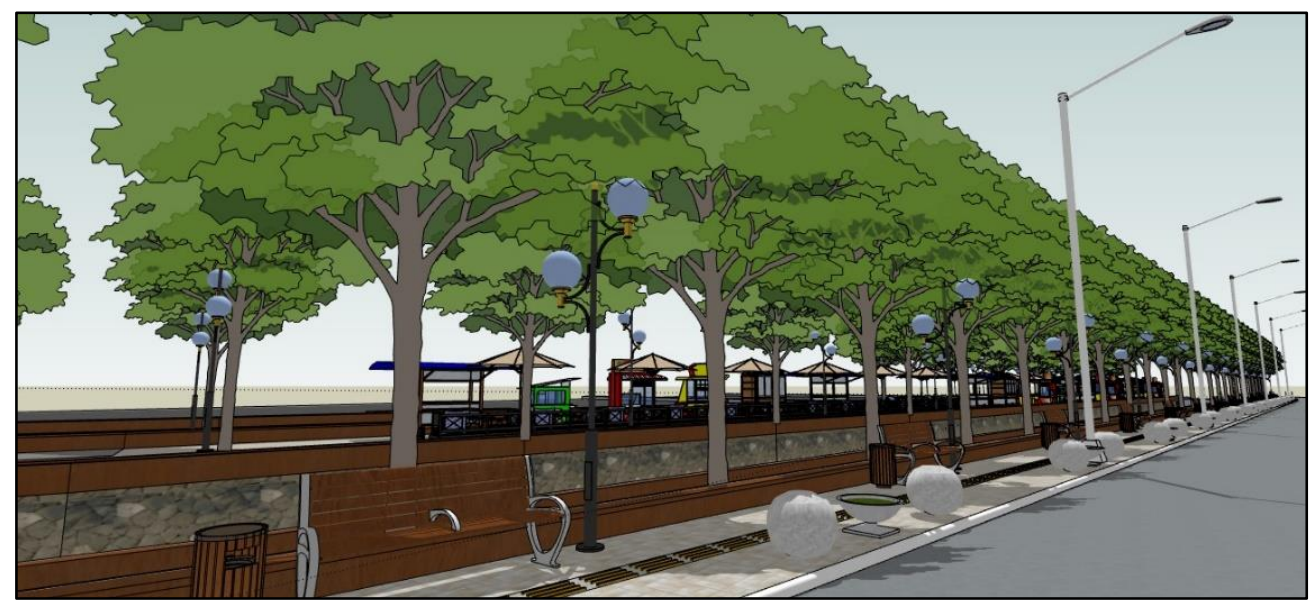

Gambar 5. Gambar Tampak Desain Pedestrian

(Sumber : Rencana Desain, 2020)

Rencana desain sentra kuliner direncanakan menggunakan konsep ruang luar (outdoor) dikarenakan area ini tidak boleh dibangun suatu bangunan, sehingga dibuat konsep sentra kuliner ruang terbuka seperti pada desain berikut ini : 


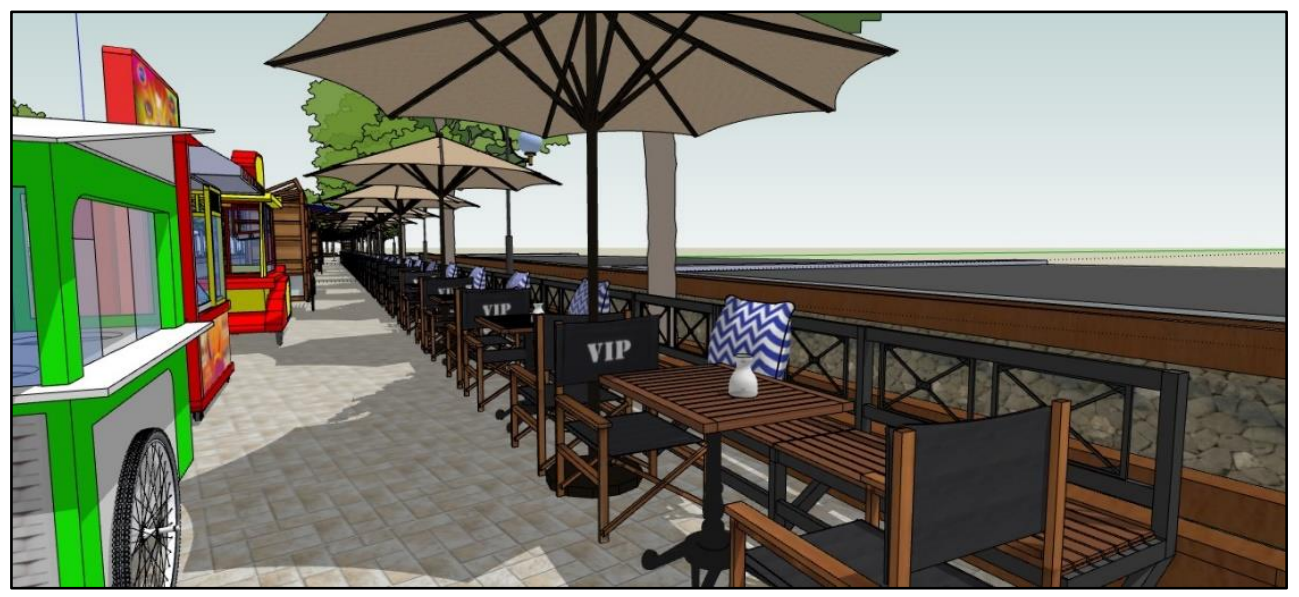

Gambar 6. Gambar Desain Sentra Kuliner

(Sumber : Rencana Desain, 2020)

Pada Gambar 6 dapat dilihat bahwa konsep yang digunakan adalah ruang terbuka, dimana disini dapat membuka tempat untuk para pedagang yang menggunkan gerobak / mini kios untuk dapat berjualan disini dengan bangunan non permanen. Disini stakeholder dapat menyediakan layanan tempat duduk untuk kenyamanan pengunjung.

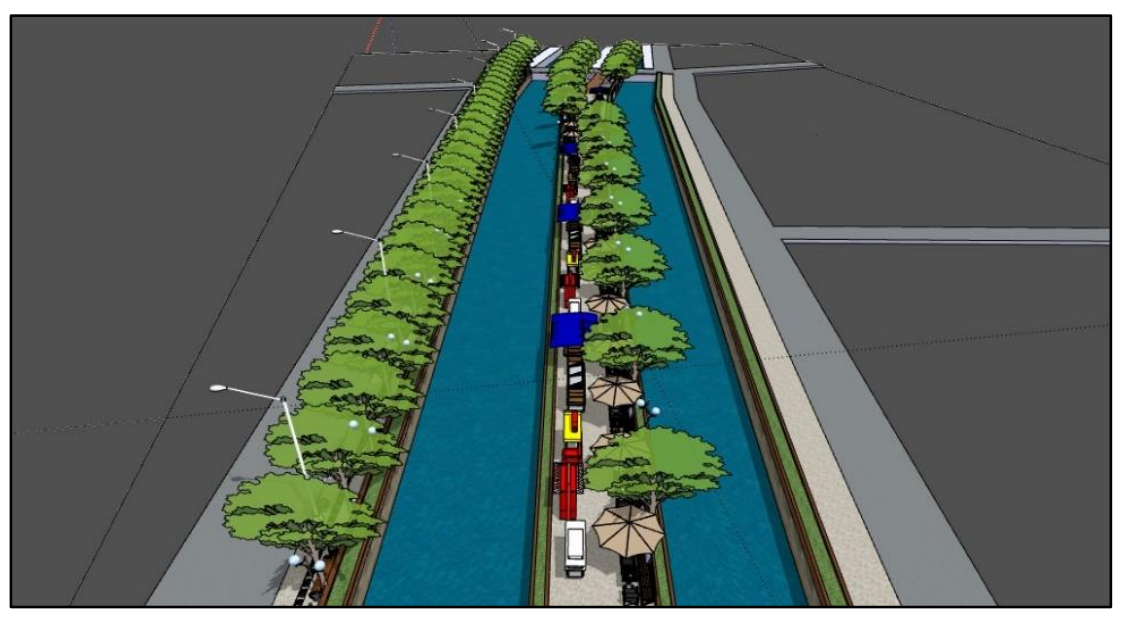

Gambar 7. Layout Rencana Pedestrian dan Sentra Kuliner

(Sumber : Rencana Desain, 2020)

\section{KESIMPULAN}

Dari hasil observasi dan rencana yang telah dilakukan, maka Desa Candinegoro dapat mengembangkan desa menjadi Desa Wisata dengan mengusung Candi Dermo sebagai sentral point lokasi wisata dan menggandeng sentra kuliner sebagai prasarana penunjang wisata untuk mewujudkan lokasi wisata yang layak dikunjungi, menimbulkan rasa senang, indah, nyaman, dan bersih, memiliki aksesbilitas yang tinggi, serta mengurangi kesenjangan ekonomi karena dibukanya lahan terbuka sentra kuliner.

\section{UCAPAN TERIMA KASIH}

Ucapan terimakasih disampaikan kepada Perangkat Desa Candinegoro, Kecamatan Wonoayu, Kabupaten Sidoarjo, Jawa Timur, atas kerjasama dan bantuannya terkait ijin dan informasi dalam terselenggaranya kegiatan pengabdian kepada masyarakat ini, serta 
terima kasih kepada Pihak LPPM Untag Surabaya atas segala bantuan administratif yang diberikan sehingga pelaksanaan pengabdian kepada masyarakat ini berjalan dengan baik.

\section{DAFTAR PUSTAKA}

Agusbushro. (2015). Analisis Kebutuhan Prasarana dan Sarana Pariwisata di Kawasan Taman Nasional Bunaken Kecamatan Bunaken Kepulauan Kota Manado. Jurnal Spasial : Perencanaan Wilayah dan Kota. Vol.2 No.2. 122 - 131

Dinas Pariwisata dan Kebudayaan Provinsi Jawa Timur. Bidang Industri Pariwisata, Bagian 7 Tahun 2017

Ghani,Y.A. (2017). Pengembangan Sarana Prasarana Destinasi Pariwisata Berbasis Budaya di Jawa Barat. Jurnal Pariwisata, Vol IV No.1. 22 - 31.

Prayogi D. (2017). Pengembangan Potensi Wisata Kuliner Kota Malang Berbasis Sumber Daya Lokal, Jurnal Pariwisata, Vol 2, No. 1, 1-13

Sari,D.M. (2015). Partisipasi Masyarakat dalam Mengembangkan Sarana Prasarana Kawasan Desa Wisata Borobudur, Jurnal Modul Vol.15 No.2, 133 - 139.

Sugiono (2013). Metode Penelitian Kuantitatif, Kualitatif dan R\&D. Bandung: Alfabeta.

Wahyudi, I (2015). Pengembangan Sarana dan Prasarana daya Tarik Wisata. Inspire Consulting website:https://cvinspireconsulting.com/pengembangan-sarana-danprasarana-daya-tarik-wisata/ 